\title{
A DESIGUALDADE REGIONAL NO BRASIL MERIDIONAL
}

\section{LUIZ FERNANDO MAZZINI FONTOURA}

Universidade Federal do Rio Grande do Sul

Porque ese cielo azul que todos vemos ni es cielo ni es azul.

¡Lástima grande que no sea verdad tanta belleza! Lupercio Leonardo de Argensola (1562-1631)*

O Estado do Rio Grande do Sul vive uma situação de aparente contraste entre suas porções sul e norte. A Campanha, porção do pampa brasileiro, ao sul, tem no domínio dos campos a base da paisagem que formou a própria identidade cultural do gaúcho brasileiro. Entretanto, o verde do pampa que vemos não é este verde e nem é mais pampa. É o resultado do manejo de muitos que não se encontram na história dos homens contemporâneos: o gaúcho, mas não o atual, o outro, que depois de viver uma experiência coletiva virou bandido, para depois retornar como herói. Mas não era mais o gaúcho do pampa, já era o da cidade, em canção, verso e tradição.

A história do pampa americano, antes da chegada dos espanhóis e portugueses, é a da América dos seus índios, semelhante àquela contada pelo escritor uruguaio Eduardo Galeano em sua trilogia "Memorias del fuego", onde há uma recuperação da memória indígena das Américas. Se retornarmos ao passado não teremos índios e o ambiente era outro, mais seco, onde não havia as pradarias.

$\mathrm{O}$ recorte da paisagem pampiana mais recente, portanto, se refere ao modo de vida do pampa resultado do pastoreio da atividade pecuária bovina, e esta foi introduzida pelos jesuítas da Companhia de Jesus junto aos índios Guaranis. Isto seria definitivo para a configuração paisagística do pampa. Antes não havia o gado bovino, a partir deste momento, os animais e os campos se fundem em uma só paisagem.

\footnotetext{
* Introdução do tango Maquillaje de Homero \& Virgilio Expósito.
} 
O sul é conhecido pela atividade pecuária bovina de corte e se manteve em uma estrutura socioespacial latifundiária por mais de dois séculos, vivendo diferentes períodos, como na consolidação da fronteira meridional brasileira, nas indústrias do charque e frigorífica. Entretanto, em seu interior, não desenvolveu as relações capitalistas de produção, caracterizado mais pelo monopólio da terra, ou seja, pela renda da terra.

O Planalto gaúcho, primeiro Mata Atlântica, depois espaço da colonização de imigrantes europeus, desenvolveu a partir de modernização da agricultura na segunda metade do século XX, uma situação de intensa mercantilização da produção agrícola, possibilitando o surgimento da penetração das relações capitalistas que se integram ao desenvolvimento do Brasil industrial a partir dos anos 1930, através dos lavradores do cultivo do trigo e do arroz.

Este trabalho tem por objetivo analisar a formação territorial do Estado do Rio Grande do Sul e a diferenciação que se estabeleceu entre as porções da região da Campanha, porção do pampa brasileiro, ao sul, e a região do Planalto Meridional gaúcho, ao norte.

Para isto, a proposta metodológica é desenvolver a formação espacial do Rio Grande do Sul, proposta em SANTOS, desde sua ocupação pelas Missões Jesuíticas e organização das primeiras estâncias coletivas, e da introdução da atividade pecuária bovina. Em função desta ocupação territorial coletiva, padres e índios resistiram aos frequentes ataques dos portugueses, que por sua vez, avançaram pelo litoral, fundando Laguna, Colônia do Sacramento e Rio Grande. Do litoral gaúcho iniciou-se o processo de concessão das Sesmarias no sul, avançando rumo oeste e sul, apropriando-se das estâncias coletivas, dando início à expansão lusa sobre o território espanhol. Com isso, vamos definir a especificidade dentro da formação brasileira, "a apreensão do particular em um momento do todo" $(1979$, 12), "fragmentando na busca da compreensão das partes constituintes para um exame mais restrito e concreto" $(2008,70)$.

A ideia deste texto é desenvolver esta formação territorial na mesma forma como foi se desenvolvendo a apropriação da terra, ou seja, em sua fase coletiva, sesmarial e mercadológica. O término é a modernização da agricultura, já no período de expansão da indústria brasileira, onde o granjeiro é o agente fundamental para o desenvolvimento das relações capitalistas no campo, diferenciando as atividades rurais e urbanas no Rio Grande do Sul. 
A ocupação da porção meridional do Brasil começa através do estabelecimento das reduções jesuíticas dos padres da Companhia de Jesus, a fixação dos índios em aldeias, e o começo da atividade pecuária bovina e extrativa da erva-mate.

As reduções indígenas, proposta pela Companhia de Jesus, transformam a apropriação do espaço com a fundação dos pueblos e suas estâncias, mas permanece o seu uso coletivo. Após a expulsão dos jesuítas se dá a apropriação das estâncias pelos sesmeiros, que tomam para si a terra, os rebanhos e o trabalho. Tanto no sul do pampa como nos campos do Planalto as estâncias particulares se multiplicaram. Mas não entraram nas áreas de mata densa. As companhias de colonização se aproveitaram destas áreas para trazer uma população camponesa que era excedente na Europa.

Nas áreas de mato, ou bioma Mata Atlântica, se refugiaram negros escravos, índios e mestiços, depois da ocupação das áreas de campo pelas estâncias comerciais. Estas pessoas, intrusos como foram denominados, deram continuidade à extração de erva-mate, economia importante neste período. E sobre estas áreas teve início o processo de colonização dos imigrantes europeus, que se estabeleceram através de uma agricultura do tipo camponesa. A diferenciação deste campesinato levou à formação de alguns comerciantes, que aproveitaram para diversificar seus capitais na agricultura mecanizada do trigo, cultivo este há muito estimulado à mecanização, realizado em forma de arrendamento dos campos da pecuária bovina.

Com o Estatuto da Terra de 1964, a soja é associada ao trigo, tornando-se o produto mais importante pela possibilidade da exportação. Com a mecanização das lavouras, constroi-se o paradigma da modernização e o surgimento dos granjeiros. Esta diferenciação entre as relações sociais travadas a partir das lavouras mecanizadas, preferencialmente localizadas no Planalto Meridional, e a atividade pecuária bovina, características do pampa gaúcho, tem como herança a forma de apropriação da terra, o que passamos a discutir adiante.

\section{O espaço jesuíta}

A história da criação do gado bovino no Rio Grande do Sul e o extrativismo de erva-mate não podem ser explicados sem a fundação das 
missões jesuíticas do Alto Uruguai. Antes disto era ocupada por grupos indígenas nômades, que construíam suas aldeias a partir de um domínio territorial, o Guará, onde movimentavam suas habitações, o Teyi, toda vez que se esgotavam a alimentação e a caça. A sobreposição de Guarás originava conflitos entre os índios. Os Guaranis, já na era cristã, desenvolviam alguma agricultura, que juntamente com a caça, garantiam a alimentação do grupo.

Para GARCIA (2010, 49-50), independente das circunstâncias históricas, a união das Coroas Ibéricas organizou as populações indígenas em aldeias e reduções. Esta decisão foi mal recebida em Assunção, pois vinha de encontro aos interesses das encomiendas, instauradas a partir de 1555, cujo sistema permitia que colonizadores se beneficiassem da mão de obra indígena em regime de escravidão. Os padres da Bahia, entre eles Nóbrega, se mostravam contrários a essa prática. A partir de 1610 os jesuítas iniciaram a fundação de reduções no Guairá, hoje estado do Paraná, com as aldeias de Loreto e Santo Inácio Mini. Em 1611 a fundação de Santo Inácio Guaçu, entre os rios Paraná e Paraguai. Desde 1609, o Rei Felipe III, "cercado de boas influências e persuadido das vantagens políticas e militares que poderiam resultar da solução preconizada pelos jesuítas", deu ordem proibindo os colonos de recrutarem escravos na província do Guairá (LUGON, 2010, 26). O padre Antonio Ruiz de Montoya, o grande realizador dos projetos dos jesuítas, chegou em 1612 para socorrer outros padres que já não davam conta do número elevado de índios guaranis.

No Rio Grande do Sul, entre 1624 e 1631, foram estabelecidas as principais reduções em torno de São Nicolau, na margem oriental do rio Uruguai. A partir daí as reduções foram ocupando a porção central do estado sulino e parte do atual Uruguai, na região chamada de Tape, fugindo da ação dos paulistas que queriam escravizar os índios.

Os jesuítas conseguiram ocupar com os índios o território vazio que ficava a leste do Governador do Rio da Prata, com sede em Buenos Aires e do Governador do Paraguai, com sede em Assunção. Neste espaço introduziram o gado vacum, que para cada pueblo, ou aldeias cristianizadas, organizaram vários criatórios naturais chamados de estâncias. Estas reses serviram ao sustento dos que viviam na aldeia. Guilhermino CESAR (2005, 23-4) relata sobre estes criatórios naturais: que os índios catequizados levavam o rebanho manso para lugares de campos livres, e ali faziam um arranchamento onde podiam realizar o 
rodeio. Estes postos também serviam de vigilância para o pueblo, antecipando quaisquer investidas de portugueses ou espanhóis. Para o autor:

Os missionários jesuítas, lançando a semente de suas reduções à margem do rio Uruguai, moveram-se para o interior, em demanda do mar, mas não chegaram às praias do Atlântico. Seus núcleos pioneiros, os pueblos da tradição colonial espanhola, conseguiram, entretanto, projetar-se economicamente por meio das vacarias. Muitos aborígenes,

reprimido o seu nomadismo, nas Missões Orientais, pela tentativa que se fez para grudá-los ao solo, ao labor agrícola, desforraram-se da constrição dispersando-se em leque - uma parte foi para os campos da margem direita da Lagoa dos Patos, na bacia oriental, e a outra saiu em demanda do Planalto Médio e dos Pinhais de Cima da Serra.

Neste corredor autárquico, como nos fala o autor, a Companhia de Jesus garantiu a autossuficiência do índio através do trabalho regular: uma agricultura de subsistência, o extrativismo da erva-mate e a pecuária bovina. Era o começo da estância, e neste tempo era de todos que nela viviam. Fora da estância, o gado criado solto, não tratado, retornava ao estado selvagem onde era caçado, principalmente quando o couro passou a ser valorizado. O rebanho livre e com abundância de pastagem foi ocupando as terras em direção ao atual Uruguai e em direção ao mar. Daí a denominação de Vacaria do Mar, caminho rumo à Lagoa Mirim (GARCIA, 2010, CESAR, 2005,). Abrindo em leque a partir da margem esquerda do rio Uruguai (Tape), o rebanho alcançou a margem direita da Laguna dos Patos; em outra parte do rebanho, partiu em direção aos Campos de Cima da Serra, sendo chamada de Vacaria dos Pinhais, ou campos de vacaria, onde hoje se localiza a cidade de mesmo nome, até o limite físico dos taimbés (ou itaimés); ao norte, os campos de Lages, em Santa Catarina. Não por acaso, este foi também o caminho das tropas de gado rumo às feiras de Sorocaba, e as primeiras estâncias em São Francisco de Paula-RS.

Da Vacaria do Mar, maior em extensão, se deu a origem da prea (captura) do gado, da cultura do manejo com estes animais, se desenvolveu a habilidade do índio (depois mestiço) cavaleiro na formação do gaúcho, como destaca CESAR $(2005,35)$ : 
Mas através de Maldonado, do Cebollatí e notadamente do magma pecuário em que se constituíram as Vacarias do Mar, o Rio Grande em formação absorveu incontáveis manadas de vacuns, muares cavalares, criados entre o futuro departamento uruguaio de Minas e a fronteira atual, no município de Santa Vitória do Palmar. E ali rebentou o sol da História, tendo a pecuária como atividade exclusiva, que o modelou, um tipo bem individuado dentro do complexo econômico sulamericano: el gaucho, o precursor do nosso gaúcho.

Em 1630 os bandeirantes atacaram e apoderaram-se dos índios do Guairá. Os remanescentes das reduções de Loreto e Santo Inácio Mini abandonaram a região com os jesuítas e se estabeleceram entre os rios Paraná e Uruguai. Em 1633 é abandonada a última redução no Guairá. Sucessivas investidas dos portugueses em busca de escravizar índios foram destruindo as reduções ao oriente do Rio Uruguai, culminando em 1638. Em 1640-41, os bandeirantes investiram contra as reduções da margem ocidental, mas foram repelidos pelos guaranis, desta vez armados e mais preparados para a guerra, na batalha de M'Bororé. Após este episódio criou-se um desinteresse da Coroa Espanhola pela região, restando um vazio demográfico preenchido pela grande oferta de gado vacum. Em 1640 começa o expansionismo luso-brasileiro (GARCIA, 2010, 55), porém, pelo litoral até a foz do rio Paraná.

Em 1680 os portugueses fundaram Colônia do Sacramento, enclave luso em frente a Buenos Aires, que serviu de entreposto para exportação da courama do gado da Vacaria do Mar, como também do contrabando do ouro e prata espanhóis. Em 1682, os jesuítas e os índios retomaram a margem oriental do Uruguai, fundaram os Sete Povos das Missões e reorganizaram as estâncias. A convivência com Colônia não chegou a ser um problema, visto que os portugueses faziam o caminho pelo litoral. De uma forma geral, de 1641 a 1732 o crescimento populacional foi intenso nas missões, obrigando a criação de novos pueblos. Duas epidemias diminuíram a população, até 1740 , retomando o crescimento novamente, segundo MAEDER (2004, 190).

O Tratado de Madri, em 1750, permutou Colônia do Sacramento pelo território das missões, e exigiu a retirada dos povos guaranis. Segundo ORNELLAS $(1956,83)$, "em Minas os homens de São Paulo iam e ficavam. Ao sul, na primeira metade do século XVII, nem ficavam nem deixavam ficar os jesuítas...", prejudicando o povoamento pacífico, levando a guerras desnecessárias anos mais tarde. 


\section{A concessão da terra ao estancieiro e o surgimento do intruso.}

Colônia do Santíssimo Sacramento foi o porto natural mais adentrado no Rio da Prata. Destruída várias vezes, também se reergueu por outras tantas. Tanto na fundação, quanto em 1704, houve participação dos guaranis, cedendo seus cavalos e alimentação, como forma de prestação de serviços à Coroa Espanhola (LUGON, 2010, 80). Esse entreposto serviu para desvio de riquezas de Buenos Aires, mas também como moeda de troca territorial entre Portugal e Espanha.

Visando à ocupação da margem esquerda do Prata, os portugueses começaram a distribuir glebas de terras em regime de concessão, chamadas de sesmarias. Esta foi uma política aplicada em Portugal no fim do período feudal, que tinha por objetivo o melhor aproveitamento das terras e o aumento da produção de alimentos, intensificando a agricultura. No Brasil, dada a vastidão de terras com baixa densidade populacional, principalmente no sul, esta distribuição assumiu muito mais o caráter de apropriação territorial. As primeiras concessões sesmariais começaram pelo litoral do Rio Grande do Sul no ano de 1732, próximo de onde hoje se localizam as cidades de Tramandaí e Cidreira. A partir deste momento se multiplicaram as sesmarias em direção às barrancas de São José do Norte, seguindo o litoral gaúcho. Com a fundação da cidade do Rio Grande, em 1737, no início uma praça de armas, abriu-se um caminho seguro entre Colônia e Laguna, esta fundada por paulistas à época da fundação de Colônia. Portugal já previa que não conseguiria se manter por muito tempo em frente à Buenos Aires com um negócio tão lucrativo como o contrabando de prata. Por isto tratou de ampliar o território ocupado para o sul, garantindo a exploração do enorme rebanho bovino da Vacaria do Mar (GARCIA, 2010, 112-3), ligando Rio Grande ao caminho de Chuí e Castilhos, no atual Uruguai. No caminho se encontravam várias estâncias, como escreve CESAR $(2005,64)$ :

De fato, a Comandância Militar, criada em consequência da expedição de Silva Paes, formou nas proximidades de Rio Grande de São Pedro, onde se instalou duas estâncias reais a de Bujuru e a de Tororotama (ou Torotama). Ali se acolheram inúmeras cabeças de gado vacum e cavalar, para atender a necessidade da tropa e da população civil.

Tomada a foz da Laguna dos Patos, a marcha lusa seguiu para o oeste em direção à Campanha. Do litoral para o interior, as sesmarias e a 
fundação das vilas foram se consolidando com a chegada dos imigrantes açorianos em Viamão e Porto Alegre. Em direção ao centro, pela margem esquerda do rio Jacuí, o povoado de Santo Amaro, que defendia a entrada de Porto Alegre. Estrategicamente os domínios portugueses seguiram em direção ao Planalto Sul-Rio-Grandense, a exemplo das cidades de Piratini e Caçapava do Sul.

O Tratado de Madri estabeleceu a troca do território de Colônia do Sacramento pelo território das Missões. Os portugueses exigiram a retirada dos índios das reduções deste território, que revoltados, iniciaram a Guerra Guaranítica. A derrota para os portugueses resultou na expulsão dos jesuítas e a destruição de todo o trabalho destes e dos índios. Iniciou-se uma imediata distribuição das terras para novos sesmeiros, que seguem o modelo de criação de gado bovino, só que agora em forma de produção privada. Os sesmeiros eram lusos que tinham prestado serviços para a Coroa Portuguesa, militares ou não, e tropeiros que conheciam bem a região e já desenvolviam algum tipo de curral ou rincão, ou seja, lugares onde já aprisionavam o gado selvagem para comercializá-lo em outro momento.

Segundo MAEDER (2004, 117-119), a população indígena guarani cristianizada sofreu uma série crise, provocada pela rápida mudança de dirigentes, tanto oficiais como de orientação religiosa, que tinham um comprometimento diferente com esta população, a qual teve uma orientação razoavelmente isolada do mundo e dos valores da sociedade colonial dada pelos padres jesuítas. A estrutura missioneira foi desmontada, os pueblos e suas estâncias não mais existiam. Assim, a integração com a sociedade colonial que crescia à sua volta se deu através do contato direto, que fomentava atitudes individuais, o comércio e a mestiçagem, em um sistema de valores contraditório à vida política, social e religiosa a que estavam acostumados. A antiga disciplina foi rompida. Para Maeder o dado mais significativo foi a diminuição da população: de 88.828 habitantes em 1768 para apenas $38.430 \mathrm{em}$ 1802. Epidemias, fuga de jovens em idade de procriar, crise demográfica e desintegração da estrutura social conduziram à ruralização da população missioneira.

Como toda pessoa ocupa um espaço, os remanescentes dos índios guaranis das missões que sobreviveram ao massacre, somados aos mestiços e à população negra descendente de escravos, tinham que ocupar algum lugar. Os índios não retornaram para a mata ou a vida selvagem. Já tinham se habituado à rotina do trabalho nas reduções, ainda que preferisse a 
atividade pastoril ao trabalho na lavoura. Poucas alternativas existiam para tocarem suas vidas fora da região de mato, da condição de andarilho errante ou permanecerem como agregados na estância privada. Como o rebanho deixado das reduções e as estâncias tinham dono a partir de então, restavam os ervais como o outro produto de valor comercial deixado de herança dos tempos das reduções. Muitos migraram para o lado argentino e outros para o noroeste uruguaio, onde ficava a maior das estâncias guaranis, o yapeyú. Os novos estancieiros-sesmeiros se apropriaram da terra, do gado e da força de trabalho deixados pelas reduções.

Grupos de pessoas não proprietárias de terra se dirigiram para o trabalho nas estâncias, como peões ou agregados com serviços diversos; e outros se somaram aos foragidos da lei da época e se dirigiram para o mato, em busca do extrativismo da erva-mate, uma vez que as terras onde se localizava o erval não interessavam ao sesmeiro. Este grupo foi identificado como os intrusos. Segundo ZARTH $(2002,87)$ :

O extrativismo de erva-mate foi, durante muito tempo, uma forma de sobrevivência para milhares de homens livres pobres. Encurralados pelos latifúndios pastoris, esses homens embrenhavam-se nas florestas em busca do mate, ao mesmo tempo, dedicavam-se à agricultura de subsistência, como típicos camponeses. Os ervais, em grande parte, localizavamse em terras públicas, devolutas, sobre as quais os lavradores nacionais pobres avançavam lentamente, disputando-as com os indígenas, as principais vítimas do processo de expropriação. $\mathrm{O}$ avanço de lavradores pobres na floresta era anônimo e espontâneo. Em 1835, os vereadores de Cruz Alta informavam que as terras que um brigadeiro, enviado pelo governo, pretendia explorar não eram desconhecidas e que nelas 'se fabricão imensa herva-matte'.

As áreas de mato foram se tornando local de refugiados, e ao mesmo tempo uma economia importante, pois além da erva-mate, o excedente gerado a partir da agricultura de subsistência realizada pelos intrusos, era comercializado nas cidades próximas, garantindo o abastecimento de gêneros alimentícios, visto que o latifúndio do gado bovino não produzia alimentos. 
Com a Lei de Terras de 1850 a terra passou a ser uma mercadoria, podendo ser comercializada, acabando com o vazio deixado pelo fim do sistema de concessão de sesmaria, ocorrido com a independência do Brasil em 1822. Neste período as áreas de campo nativo estavam ocupadas pela atividade pecuária bovina, restando somente as áreas de mato. A possibilidade de sua comercialização movimentou o mercado imobiliário e de colonização, pois esses projetos contavam com subsídios oficiais, aumentando a expectativa de ganhos. Inclusive despertou o interesse dos grandes proprietários de terra, que passaram a ver as reservas de mato no interior de seus estabelecimentos, como possibilidade de valorização. Para ZARTH $(2002,93)$ :

A colonização do Sul com imigrantes europeus não foi exclusividade do Estado. Ao contrário, foi um negócio altamente rentável para empresários que detinham terras de forma fraudulenta ou mesmo legais e as vendiam aos imigrantes na forma de pequenos lotes coloniais. Mas estes empreendimentos, de modo geral, estavam amparados pela colonização oficial subsidiada pelo Estado, e desenvolviam-se nas proximidades das Colônias, usando em maior ou menor grau a infraestrutura do oficial.

Os novos colonos camponeses oriundos de vários países da Europa, mas principalmente alemães e italianos deveriam pagar pelo lote, enquanto na colonização privada, o Estado subsidiava ao colonizador por pessoa assentada, na maioria das vezes cobrindo na totalidade o investimento realizado. Nos anos 1850, o processo de colonização paralelo à manutenção da escravidão era bem visto, ao mesmo tempo em que atendia a outras demandas da época. A população escrava era bastante numerosa, e frente aos reclames abolicionistas, havia uma preocupação constante de revolta pelos escravos. Segundo SILVA $(1996,128)$ :

Em relação à imigração, a visão Saquarema retomava as ideias de povoamento do amplo território nacional existente desde os tempos de D. João VI e dava ênfase particularmente à necessidade do branqueamento da população por meio da introdução de imigrantes europeus (inicialmente alemães e suíços), e na difusão da pequena propriedade por intermédio 
da venda de lotes de terras recortados nas terras devolutas da Coroa.

Todos os imigrantes deste tipo eram chamados de colonos, tanto na colonização oficial, realizada pelo Estado, como a particular, onde os colonizadores financiavam a viagem dos imigrantes.

\section{A mercantilização da área de mato e a sua colonização}

No Rio Grande do Sul, pela forma da ocupação e construção da linha de fronteira, a atividade pecuária bovina e a formação da estância foram fundamentais. Assim, as áreas de campo foram tomadas em sua totalidade. As áreas de mato, embora representassem uma fonte de economia, como no caso da erva-mate, foram apropriadas com a finalidade da colonização. Com a independência do Brasil no ano de 1822, a população dos lavradores nacionais teve que se retirar para dar lugar ao processo de colonização. Como descreve BERNARDES $(1963,33)$ :

Os colonos imigrantes ou seus descendentes dirigem-se sempre para a mata. O povoamento se expande, então, sobre os troncos abatidos; 'colonizar e desmatar são sinônimos', sintetizou, muito bem, Pierre Denis. Isto aconteceu, não tanto porque os colonos chegaram quando já os campos estavam divididos pelas fazendas de gado, ou porque os proprietários

das mesmas não se desfizessem de parcela alguma que viesse a prejudicar seu sistema extensivo de criação. Imprimindo os rumos iniciais da colonização, o governo deu ao colono a tarefa de fazer recuar a mata virgem, e isto era uma razão importante. Mas acima de tudo, o que sucedeu com os imigrantes europeus é que eles se fizeram herdeiros da tradição luso-brasileira de que a agricultura só seria proveitosa na mata, onde o solo humoso compensava o trabalho e a semeadura.

Existia, segundo o autor, com base em outros estudos, a crença de que os solos de campo eram fracos para a agricultura, como de fato em algumas áreas o são. Estas terras de mato, principalmente as do Planalto Meridional, são mais propícias para a lavoura. Sendo assim, as áreas de 
colonização se deram, preferencialmente, em áreas de maior densidade de florestas, conforme a figura abaixo:

Figura 1. Povoamento do Estado do Rio Grande do Sul sobre área de mata.

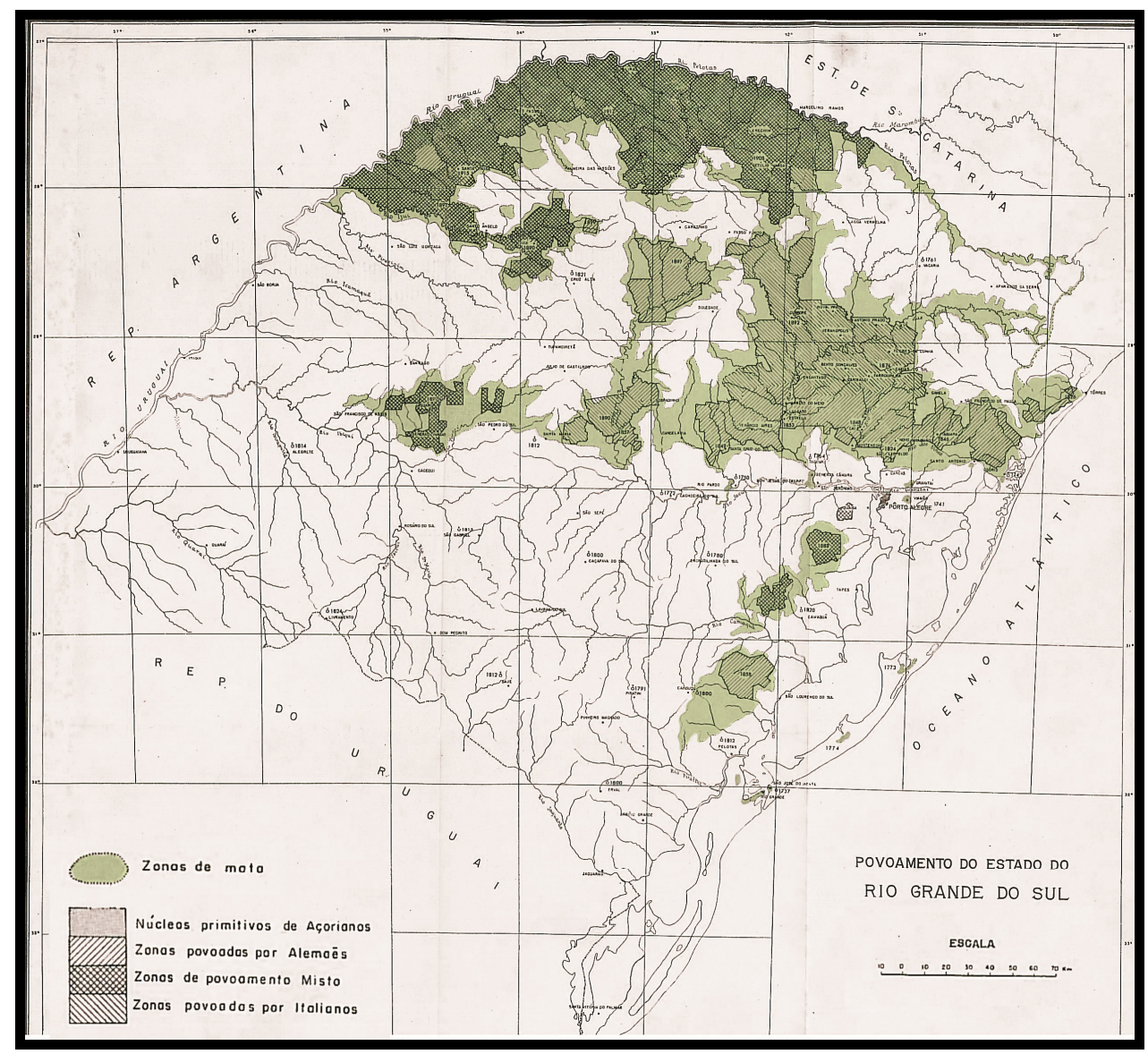

Elaborado por Sommer, Ana Cândida, adaptado de: BERNARDES, Nilo. A colonização e povoamento do estado do Rio Grande do Sul. IBGE. 1963.

O mapa mostra nas áreas escuras a predominância de florestas (Bioma Mata Atlântica), e nas hachuradas as áreas colonizadas. Sobre a 
mata densa não havia o domínio das estâncias, não era áreas de pastoreio, portanto. Somado a isto, segundo Bernardes, a colonização açoriana não chegou a constituir os núcleos de densidade demográfica que diminuíssem os efeitos de uma população rarefeita, resultado da atividade pastoril. O Brasil procurava um novo tipo de colono que fosse proprietário livre para ocupar e cultivar as áreas de mato, e que não estivesse interessado no trabalho escravo e nem na criação de gado, atividade que se desenvolveu no Bioma Pampa.

Para WAIBEL (1958, 210-11), o início da colonização nas terras florestais do Brasil meridional se deu após o ano da independência, e tinha como objetivo principal povoar as terras de mato para evitar o ataque dos índios, e aumentar a densidade demográfica, diminuindo os riscos dos ataques argentinos. "O novo tipo de colono deveria ser tanto um soldado quanto um agricultor, para poder defender sua terra quanto cultivá-la”. Waibel escreve que este colono se encontrava na Europa central, onde os soldados desengajados do exército de Napoleão e camponeses pobres e famintos estavam prontos para migrar para qualquer parte do mundo (1958, 212). Em 1824, distante $24 \mathrm{~km}$ de Porto Alegre, em direção ao norte, no vale do rio dos Sinos, fundou-se a primeira colônia de alemães, que recebeu o nome de São Leopoldo. A colônia cresceu rapidamente na direção das encostas florestais da serra. Além de camponeses, se estabeleceram, também, uma grande quantidade de artesãos, desenvolvendo rapidamente a atividade industrial e a agrícola.

Seguiram-se outras colônias nos estados do Paraná e Santa Catarina, com o mesmo objetivo, de povoar e guardar os caminhos das tropas de gado do Rio Grande para São Paulo. Na direção oeste de São Leopoldo, em 1849, foi fundada uma das mais importantes colônias, a de Santa Cruz. Contornando a borda da mata nos contrafortes da escarpa do Planalto Meridional, esta colônia se caracterizou pela produção de fumo como principal lavoura comercial. Entre as duas colônias, segundo Waibel, havia uma enorme selva, onde apenas alguns intrusos luso-brasileiros tinham penetrado. Por volta de 1870 , os colonos alemães tinham ocupado quase a totalidade da borda do planalto.

Na década de 1860 até 1870 diminuiu a imigração alemã. Isso aconteceu porque a Prússia promulgou, em 1859, o chamado rescrito de Heydt, que proibiu a propaganda brasileira em favor da emigração para o Brasil, devido ao mau tratamento sofrido pelos alemães no Estado de São Paulo. Assim, o governo transferiu sua propaganda para a Itália, 
principalmente na região de Vêneto, para dar continuidade ao projeto colonizador. Seguiu-se, assim, a fundação das colônias de Caxias do Sul, Garibaldi e Bento Gonçalves. Em 1890, um ano após a Proclamação da República, fundou-se a colônia de Ijuí, a colônia nova, que tinha a característica de ser uma colônia mista do ponto de vista étnico, onde muitos colonos eram originários da colônia de São Leopoldo, chamada de colônia velha. Próximo à colônia de Ijuí, por iniciativa privada, fundou-se a Katholicher Bauernverein Von Rio Grande do Sul, ou a Associação dos Agricultores Católicos do Rio Grande do Sul, em 1902. Desta colônia se originou a de Neu-Württemberg, hoje Panambi (WAIBEL, 1958, 216-7). Essas colônias formaram o epicentro da modernização da agricultura do trigo e da soja.

Entretanto, ainda segundo WAIBEL (1958, p. 226-241), nem todos os colonos tiveram a mesma oportunidade de produzir suas terras em condições adequadas. $\mathrm{Na}$ busca pela sobrevivência, os colonos desenvolveram três estágios de sistemas de uso da terra:

a) o sistema de rotação de terras primitivas: sistema herdado do caboclo (lavrador nacional), que consistia na derrubada da mata e o cultivo de milho, feijão e mandioca, usando uma cavadeira e enxada primitivas;

b) sistema de rotação de terras melhoradas: depois que a mata é devastada e que a densidade da população aumentou com o auxílio das estradas, foi possível se introduzir outros tipos de cultivos como a batata inglesa, o trigo e o centeio no inverno, e o arroz no verão. Nos cruzamentos das estradas começaram a se estabelecer os moinhos de famílias de antigos comerciantes. O desenvolvimento da pecuária de suínos e aves deu uma aceleração nas atividades da região colonial, que trocou os seus produtos com as cidades maiores, de origem lusa, e que sofriam com o desabastecimento;

c) sistema de rotação de culturas combinada com a criação de gado: com as terras aradas com tração animal alguns colonos conseguiram associar a lavoura à criação de gado, o que ajudava na adubação da terra, permitindo a alternância de cultivos de cereais com cultivos de raízes e leguminosas para enriquecer o solo com nitrogênio.

No entanto, o tamanho médio dos lotes em área de mata tinha entre 25 e 30 hectares, o que dificultava a passagem de um sistema para o outro. Nas áreas montanhosas, o lote era demasiado pequeno para desenvolver o primeiro sistema e passar para o segundo. Assim, longe das estradas e da 
atividade do comércio, bem como do colégio para os filhos, alguns lavradores ficaram reféns dos comerciantes, seu único contato com o mundo distante, e que enriqueceram às suas custas. $\mathrm{O}$ projeto de colonização, segundo Waibel, não observou o que chamou de minimale Ackernahrung, ou seja, uma quantidade mínima de terra para garantir um bom padrão de vida para o agricultor. Consequentemente, aqueles colonos que não conseguiram sair do primeiro estágio, migraram para a fronteira agrícola, abandonando ou vendendo seus lotes. Waibel entendia que os lotes deveriam ter entre 55 e 65 ha em terra considerada de boa qualidade, e de 85 e 105 ha em terra ruim.

Diante dessa situação, muitos filhos de colonos europeus pobres, considerados caboclos a partir de então, partiram para a cidade ou em busca de novas terras na direção do oeste catarinense e da região CentroOeste. Ao contrário, àqueles que conseguiram diversificar na lavoura e no comércio, acumularam riquezas e também diversificaram atividades comerciais nas cidades coloniais que cresciam economicamente. Este sujeito com capital disponível e com tradição agrícola estava pronto para a produção e reprodução das relações sociais capitalistas.

\section{O espaço capitalista dos granjeiros.}

Os primeiros estímulos à mecanização do campo nas lavouras de arroz e trigo datam de 1920. A herança do pensamento positivista, com base na ideia de progresso e industrialização, fez com que Getúlio Vargas apresentasse projetos de intensificação na produção e elevação da produtividade de alimentos, em razão do abastecimento da população urbana, que haveria de crescer estimulada pelo aumento da produção industrial.

A influência de Getúlio Vargas como ministro da agricultura para a organização dos criadores de gado bovino, acrescida da pressão exercida pelos frigoríficos, ajudaram no refinamento das raças diferenciando o rebanho gaúcho, principalmente na região da Campanha, principal região criadora de animais do estado. Pelo lado da lavoura, a produção de trigo, já conhecida nas terras gaúchas desde os açorianos, teve motivação maior através de linhas de créditos o que proporcionou as bases da mecanização desta lavoura. Quando Presidente da Província, ainda que por dois anos (1928-1930), Vargas estimulou a produção de trigo e arroz, sendo estes os primórdios da lavoura mecanizada sob orientação do Estado, ampliados 
quando chegou à Presidência da República. Estimulou, também, a associação de produtores, a começar pela Federação das Associações Rurais e o ressurgimento da Federação da Agricultura do Estado do Rio Grande do Sul (FARSUL), como forma de organizar os produtores para o recebimento do crédito rural.

Ao chegar ao Governo Provisório em 1930, Getúlio Vargas já havia deixado no Estado do Rio Grande do Sul as bases para o acesso ao crédito junto à comunidade rural. Vargas no governo do estado aproximou grupos políticos opostos propondo a união dos produtores pelo cooperativismo e a sindicalização destes, promovendo meios para o desenvolvimento $\mathrm{e}$ aperfeiçoamento dos transportes e o crédito rural. Ainda em 1928 é criado o Banco do Rio Grande do Sul, cuja iniciativa tem apoio da jovem FARSUL. Vargas lançou as bases para a produção tecnicamente avançada do trigo, estimulou a pesquisa que deu origem às variedades melhores e de adaptação mais fácil ao meio. A limitação à importação de trigo estimulou os produtores locais.

O trigo se desenvolveu na chamada colônia nova onde se localizam as cidades de Ijuí e Panambi. Sem a possibilidade da produção pecuária bovina, pela concorrência com as estâncias do sul do estado, os produtores imigrantes optaram pelos cultivos do milho, o feijão preto, a mandioca, a soja e trigo, e a criação de suínos.

Além dos estímulos criados desde os anos 1930, o trigo recebeu grande incentivo a partir de 1944 através de uma política de apoio do Governo Federal onde foi criado o Serviço de Expansão do Trigo (SET), coordenado pelo Ministério da Agricultura com uma política específica para o setor, distribuindo gratuitamente sementes para as cooperativas; fiscalizou a comercialização e a industrialização. Também determinou quotas que seriam compradas para a moagem pela indústria. A partir deste ano se estabeleceu uma política de preços mínimos para diversos produtos agrícolas, incluindo o trigo nesta política. Essa garantiu uma rentabilidade mínima ao capital investido na lavoura.

No sentido de garantir o abastecimento de pão para as grandes cidades, esta política de preços despertou o interesse de um leque de interessados que viram nela a estabilidade para seus investimentos. Em 1955, o armazenamento foi tratado com mais vigor. Em 1957 foi criada a Comissão de Organização da Triticultura Nacional (COTRIN) cuja consequência imediata foi o zoneamento das regiões produtoras e suas cooperativas, por onde se realizaram a distribuição de crédito, 
armazenamento e o comércio. Em 1959 foi criada a Comissão de Organização da Triticultura Nacional e Armazenamento Geral (COTRINAG), que passou a incluir outros produtos. Ambas, COTRIN e COTRINAG tiveram importante papel para a organização das cooperativas tritícolas no Rio Grande do Sul.

As condições ambientais favoráveis do Planalto gaúcho fizeram com que a partir de 1946 começassem as primeiras lavouras mecanizadas em Passo Fundo e Carazinho, Ijuí e Santo Ângelo, e a seguir, nos demais municípios do Planalto. Os primeiros a se tecnificarem foram os produtores que já dominavam a linguagem dos negócios bancários e comerciais na cidade, como comerciantes, profissionais liberais, que tendo um passado próximo com a agricultura viram nesta atividade uma oportunidade de diversificação de capitais. Esta classe de produtores ficou conhecida como os granjeiros do Planalto (FRANTZ, 1982).

Neste momento não participaram da mecanização da lavoura os produtores familiares ou colonos, como são conhecidos, pois não conhecendo a linguagem dos negócios capitalistas que se instalavam, viram com desconfiança o novo sistema de produção, pois além dos trâmites bancários, a entrada no novo sistema implicava a hipoteca da terra. O campesinato não compreendia a linguagem do Estado, da sua organização e disciplina. Eles foram sobreviventes do processo de acumulação de terras dos colonos comerciantes, que se beneficiaram da renda da terra, por ocuparem terras mais férteis e localização privilegiada, resultando em uma diferenciação do campesinato destacada por Waibel e Bernardes. A entrada em um sistema desconhecido poderia significar a possibilidade da perda da terra, como de fato aconteceu com muitos camponeses.

O ingresso dos pequenos produtores ao negócio do trigo e soja se dá a partir dos anos 1960, mas forçados pela sua inclusão no mercado e em condições desvantajosas, uma vez que as condições impostas pelas cooperativas priorizavam os interesses dos acionistas majoritários.

Em consórcio com a lavoura de milho, a soja foi introduzida no Rio Grande do Sul a partir da década de 1940 e ganhou algum espaço nos pequenos estabelecimentos. Leguminosa de clima temperado, seu plantio na estação do verão possibilitou utilizar as terras destinadas ao trigo, aproveitando-se do beneficiamento do preparo da terra. 
Para se entender a expansão da lavoura de soja no Rio Grande do Sul e no Brasil, é necessário esclarecer as mudanças de hábitos alimentares nos Estados Unidos e na Europa pós-Guerra, através da substituição da utilização da gordura animal pelo óleo vegetal. Além deste fator, a escassez de terras destinadas à pecuária nos países europeus, fez com que houvesse uma intensificação no confinamento nos rebanhos leiteiro e suíno, cuja alimentação passou a ter o farelo de soja como principal ingrediente. Seguido pelos demais países, o consumo mundial aumentou significativamente, aumentando a demanda e a área plantada nos países produtores.

No caso do Planalto gaúcho, o manejo da agricultura mecanizada com as operações bancárias e do crédito já era bem conhecido pelos granjeiros produtores de trigo, e sua adaptação era direta, pois já havia o consórcio do plantio desses com a soja. Na década dos anos 1970 se deu a forte expansão da lavoura de soja por toda a extensão do Planalto, bem como sua expansão pelo Centro-Oeste brasileiro pelo processo de migração dos colonos gaúchos, que trocavam suas terras no sul por maiores lotes na fronteira agrícola brasileira. Rapidamente a soja se tornou um dos principais produtos de exportação e a União respondeu com a infraestrutura para armazenamento, circulação e comercialização do produto.

A soja e os gaúchos cumprem com isto um importante papel nos objetivos do Estatuto da Terra. Este delegava à agricultura os papéis de alavancar o desenvolvimento econômico através de uma nova relação campo-cidade no país e essa interdependência traduziu-se nos seguintes aspectos fundamentais do processo de crescimento e integração nacionais, dando à Política de Desenvolvimento Rural um grande número de atribuições (FONTOURA, 2004). O Estatuto da Terra é um conjunto de leis que estimulam a criação da Empresa Rural, unidade produtiva capitalista que adotou o sistema de produção com base na mecanização, fertilização e uso de produtos químicos na lavoura, com o objetivo de aumentar a produtividade dos setores agrícolas e industriais urbanos.

Outras lavouras se mecanizaram e formaram suas empresas e empresários, como por exemplo, o arroz. Mas a soja se destacou e tornouse o principal produto nos mercados interno e externo. Saiu do Rio Grande do Sul e se destaca como uma lavoura predominante na Região do Cerrado brasileiro. Sob o comando de muitos granjeiros gaúchos, as lavouras de soja adentram a Amazônia e o sertão baiano (HAESBAERT, 2004). 
Com a expansão da lavoura de arroz no Rio Grande do Sul na década de 1970, muitas terras destinadas para a pecuária na Campanha gaúcha passaram a ser utilizadas para lavoura nos meses de verão. $\mathrm{O}$ casamento arroz-bovino é perfeito, pois após a colheita, o rebanho pasta a resteva (palha da colheita) e o rebrote da lavoura, enquanto pisoteia e fertiliza com seus dejetos. $\mathrm{O}$ arrendamento da lavoura para pastagem é muito utilizado. Assim gerou-se também, uma fonte complementar de renda para o pecuarista, na mesma medida em que melhoramentos de infraestrutura e água começaram a ser ofertados. Com o sistema de arrendamento, o estancieiro da pecuária bovina se beneficiou da renda da terra e se manteve até a década de 1990 com sistemas de produção extensivos, mantendo uma situação de lenta decadência da sociedade latifundiária.

Mas o processo de modernização da agricultura é exigente em relação ao tipo de solo e relevo onde pode ocorrer a mecanização, e este se estabeleceu na região do Planalto e Depressão Central. Já a região da Campanha, ou a porção do bioma pampa brasileiro, se aparentemente é homogêneo quanto à paisagem campestre, não o é em relação ao horizonte de solo e forma de relevo. Ao contrário, o Planalto Sul-riograndense, base do escudo cristalino, bem como a Cuesta do Haedo (figura 2), são bastante restritivos para a lavoura mecanizada. Isto impossibilitou o sistema de arrendamento por parte do estancieiro limitando seus ganhos à pecuária extensiva. Findado o período do regime militar nos anos 1980, e sem representação política, a decadência econômica e política foram inevitáveis. 
Figura 2. Macrozoneamento Ambiental do Estado do Rio Grande do Sul Elaborado por Sommer, Ana Cândida, adaptado de:

http://www.seplag.rs.gov.br/uploads/Macrozoneamento2.pdf

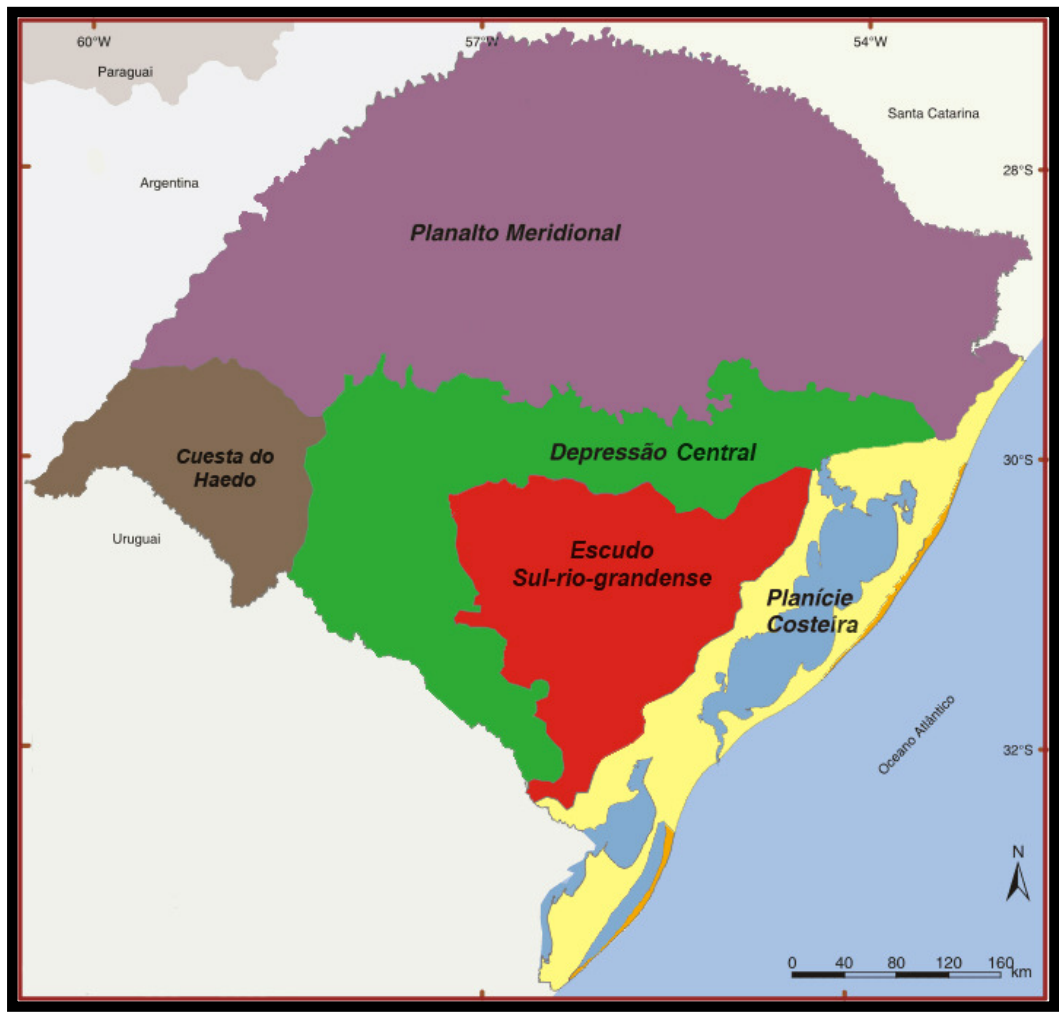

Acessado em: 20 de maio de 2011.

Por outro lado, as demandas sociais tiveram mais espaço neste mesmo período, principalmente o pleito da Reforma Agrária liderado pelo Movimento dos Trabalhadores Sem Terra (MST). Ao final dos anos 1980 e início da década seguinte, houve um grande número de assentamentos na região da Campanha. Entretanto, se observarmos com atenção a figura 3, a localização destes não se dá nas áreas preferenciais de arrendamento capitalista, porção central do Planalto e Depressão Central, ou seja, nas áreas agrícolas de uso intensivo, onde resultou a associação do granjeiro com o pecuarista, mas sim nas áreas preferenciais do latifúndio. Logo, 
estes assentamentos se localizaram nas áreas de maior restrição para lavoura, que é o sistema de produção característico do campesinato.

Figura 3. Assentamentos no Estado do Rio Grande do Sul

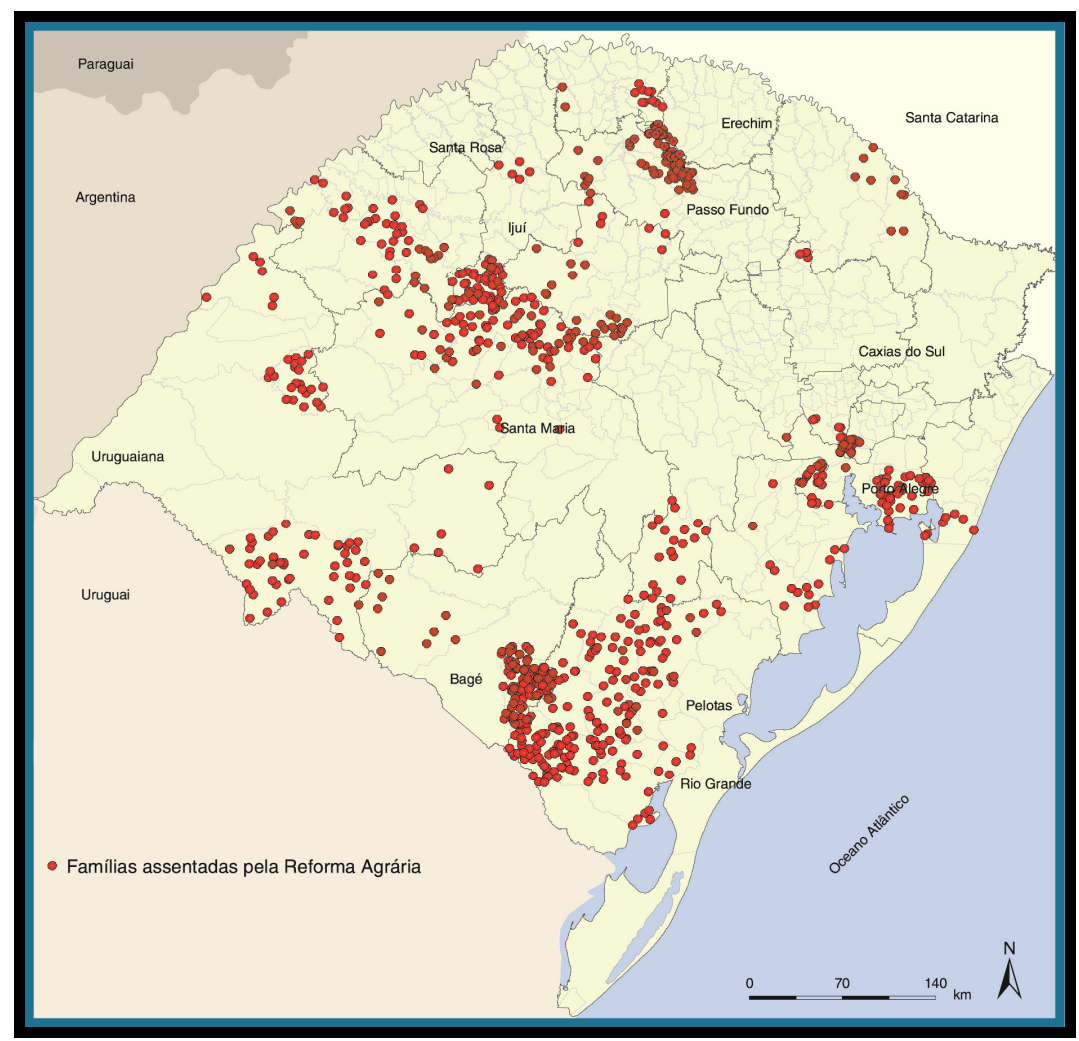

Elaborado por Sommer, Ana Cândida, adaptado de:

http://www.seplag.rs.gov.br/uploads/eco_assentamentos.pdf

Acessado em: 20 de maio de 2011

Boa parte dos camponeses assentados trouxe como herança o cultivo da soja dos lugares de onde vieram, e passaram a plantar tão logo instalados. Foram muitos os casos de perda total da lavoura por desconhecerem o tipo de solo e o déficit hídrico, característico da região da Campanha. Muitos são os relatos de endividamento na produção de soja. 
Isto colaborou para a mudança de orientação o sentido da produção de orgânicos, opção da maior parte das cooperativas da Reforma Agrária que atuam na região.

Todavia, como alternativa ao latifúndio, e com justa razão, os assentamentos trouxeram maior densidade demográfica para os municípios, movimentaram o comércio e produção local, por pressão dos próprios assentados. Houve, também, mudança no perfil político, aumentando o número de municípios emancipados. Aumentou o número de demandas sociais as quais muitas não foram atendidas. E isto tudo é benéfico. Porém, do ponto de vista das relações sociais, a região da Campanha continuou aquém da apropriação capitalista do espaço como se deu na região do Planalto, onde a lavoura da soja encabeçou o processo da modernização da agricultura, associando consigo uma série de atividades de serviço e produção industrial ligado ao agronegócio. Como resultado, toda vez que se estabelecem parâmetros comparativos entre uma região e outra, o Planalto aparece como uma região plenamente desenvolvida frente à outra, a Campanha, subdesenvolvida.

$\mathrm{Na}$ comparação dos dados gerais entre uma região e outra, Planalto e Campanha, nesta predomina a média das áreas de restrição, mascarando as áreas onde há empreendimentos capitalistas, como no caso das lavouras de arroz e da pecuária empresarial, de genética especializada comparável aos rebanhos argentinos (FONTOURA, 2000). A pecuária empresarial associa a lavoura à pecuária bovina, independente de ser o mesmo ator social ou não, melhorando a qualidade das pastagens e o fornecimento de alimentação para o rebanho bovino. $\mathrm{O}$ melhoramento dos campos naturais com a introdução de espécies nobres de pastagem é outra técnica utilizada pelos produtores. O processo consiste em introduzir a semente ao solo após o pastoreio, lançando-a e pisoteando-a. Outra forma é a utilização de máquinas com o fim específico de semear forrageiras, que abrem leves sulcos na terra, introduzindo a semente e o adubo. Este método simples e de baixo custo, melhora sensivelmente a produtividade dos campos. Mas isto só ocorre nas áreas apropriadas para lavoura intensiva, que podemos observar na figura 2 onde ocorre de forma mais intensiva na depressão central.

Aproveitando-se da oferta dos campos da pecuária extensiva colocadas à venda, outras duas formas de sistema de produção têm expandido em área: a viticultura e a silvicultura. A primeira, mais charmosa, tem sido bem recebida pelas populações locais e pela produção 
de trabalhos no meio acadêmico, pois a produção de vinhos remete a um produto de grande aceitação, além da formação de terroir próprio, que tem valorizado a região. Diferentemente da região dos vinhedos da "serra gaúcha", a viticultura que se desenvolve na região da Campanha pertence a grandes companhias vinícolas, assim como empresários bem estabelecidos. Do ponto de vista paisagístico, as grandes extensões da viticultura em nada diferem de outros monocultivos.

A silvicultura, principalmente do cultivo do eucalipto nesta região, pertence em sua quase totalidade às companhias Aracruz e Votorantin, que fundiram seus capitais com o novo nome de Fibria, visando à produção de celulose para a produção de papel. A estratégia foi semelhante às duas companhias enquanto atuaram separadas entre 1998 e 2008: a compra direta de grandes glebas de terra, às vezes estâncias inteiras, que podiam alcançar a marca de 3.000 ha, considerado grande para a região. De imediato, providenciavam o licenciamento ambiental amplamente divulgado nos veículos de comunicação impressa. Processo idêntico ocorreu na continuidade do Planalto Sul-riograndense, ao sul, pelo lado uruguaio, também tradicionalmente formado de estâncias de pecuária extensiva e com restrições à lavoura mecanizada. Aos pecuaristas familiares, de pequenos e médios estabelecimentos, foi oferecida a poupança florestal, integração de pequenos lotes de plantio de eucalipto, que ao longo do ciclo da árvore gera rendimentos ao produtor. Somada a poupança, as empresas procuram contratar o trabalho destes produtores para o manejo da lavoura arbórea, contribuindo para garantir a legitimidade local das transformações em andamento.

\section{Considerações finais.}

O Estado do Rio Grande do Sul é considerado o celeiro do Brasil, tanto pela lavoura, quanto pela atividade pecuária: suína, aves, cavalar e bovina de corte. Foi precursor da lavoura mecanizada, mas foi palco, também, dos movimentos em defesa do ambiente nos anos 1970. Entre os estados nacionais, destaca-se como o terceiro maior produtor de soja, superado pelo Mato Grosso e quase empatado com o Paraná. Procuramos mostrar que não foi apenas a condição de imigrante a base para $o$ desenvolvimento da soja, mas, houve uma construção social na ocupação e definição da linha de fronteira no Brasil meridional que definiu a lógica da localização das pessoas e de seu trabalho. Se a Geografia se preocupa em 
descrever e localizar, pensamos em contribuir neste sentido, o porquê da diferenciação regional em sul e norte do ponto de vista do desenvolvimento das relações capitalistas.

O sul, a Campanha, ou pampa, teve seu apogeu econômico em dois momentos. O primeiro no período da indústria do charque. Logo após, influenciado pela frigorificação da carne na região do Prata, propiciou o melhoramento genético no plantel bovino nos campos do pampa brasileiro. Mas a herança do sistema extensivo não permitiu a evolução de uma racionalidade empresarial na atividade pecuária bovina de corte (FONTOURA, 2000). A integração da lavoura com a pecuária só veio a acontecer na década de 1990, com programas de melhoramento genético e diversificação na cadeia produtiva da carne. Uma vez mais, seguiu o Estado do Rio Grande do Sul os avanços tecnológicos introduzidos nos países vizinhos do Prata, para novamente se diferenciar no cenário da pecuária bovina brasileira.

O norte, ou a região do Planalto Meridional, foi o berço da mecanização da lavoura nos parâmetros da mecanização e quimificação do processo produtivo. Tiveram na região do Planalto atores sociais capazes de produzir e reproduzir as relações capitalistas. Para este fim, o Estatuto da Terra de 1964-65 teve o papel de organizar os subsídios para que o pacote tecnológico se territorializasse, estreitando as formas de produção no campo e na cidade (fordismo na agricultura) (FONTOURA, 2004). Com o avanço da mecanização na agricultura, vários pequenos proprietários de estabelecimentos agrícolas migraram para os centros urbanos, inclusive a região industrial metropolitana de Porto Alegre. Entretanto, com uma economia bastante capitalizada, a região recebeu importantes investimentos e criação de postos de trabalho, elevando índices econômicos e investimentos públicos. Mesmo com uma considerável alteração da paisagem, resultado das lavouras mecanizadas, a região do Planalto apresenta os mais altos Índices de Desenvolvimento Humano (IDH), com maior renda per capita e melhor distribuição que o sul.

A modernização da agricultura do Planalto Meridional do Rio Grande do Sul teve suas origens nos acontecimentos que começam nas missões, passando pelas estâncias e os ervateiros, onde os mestiços do cruzamento do negro, índios e espanhóis, não tiveram acesso à terra. $\mathrm{O}$ processo de transformação da terra em mercadoria se dá simultaneamente aos projetos de colonização de imigrantes europeus, e isto vai diferenciar, 
não apenas a racionalidade, mas também a forma de inserção social, do colono (branco), que teve acesso à terra e à propriedade, diferentemente do peão (bugre, mestiço), que lhe foi negado. Não se trata apenas de uma questão cultural, mas essencialmente do resultado de organização territorial, de ordem espacial.

A diferenciação entre as regiões norte e sul do estado, não é apenas o resultado da análise da paisagem instantânea e seus contrastes étnicos em seu povoamento ou em seus sistemas de produção, mas o resultado de um processo diferenciador que tem suas origens desde o processo de formação do território no Brasil meridional.

\section{A DESIGUALDADE REGIONAL NO BRASIL MERIDIONAL}

Resumo: Este trabalho tem por objetivo analisar as condições em que se realizaram a penetração das relações capitalistas na região do Planalto gaúcho e a construção do paradigma da mecanização, ou modernização da agricultura. O seu principal agente é o granjeiro da soja, mas esta pessoa de origem urbana tem uma construção socioespacial que passa pela mercantilização das terras de mata, com o estabelecimento das colônias de imigrantes europeus no sul do Brasil, mas também do aproveitamento das terras destinadas à atividade pecuária bovina. A diversificação do campesinato, aliado ao capital gerado na atividade comercial, permitiu o arrendamento destas terras dos estancieiros para as lavouras mecanizadas de trigo, que se associaram às de soja a partir do Estatuto da Terra.

Palavras-Chave: desigualdade regional, colonização, pampa brasileiro

\section{THE REGIONAL INEQUALITY IN SOUTHERN BRAZIL}

Abstract: Summary: this work aims to analyze the conditions were the penetration of capitalist relations in the region do Planalto gaúcho and construction of paradigm of mechanization, or modernization of agriculture. Its main agent is the granjeiro of soya, but this urban person origin has a building socio-spatial passing through the commercialization of forest land, with the establishment of colonies of European immigrants in southern Brazil, but also exploiting land intended for bovine livestock activity. Diversification of peasant, allied to capital generated in commercial activity, enabled the lease of the land of estancieiros for 
mechanized ploughing wheat, which joined the soya from the "Estatuto da Terra".

Key-words: regional inequality, colonization, Brazilian Pampa

\section{BIBLIOGRAFIA}

BERNARDES, Nilo.(1963) As bases geográficas do povoamento do estado do Rio Grande do Sul. IBGE. Rio de Janeiro.

CESAR, Guilhermino. (2005) Origens da economia gaúcha (boi e poder). IEL/Corag. Porto Alegre.

FONTOURA, Luiz F. M. (2000) Macanudo Taurino: uma espécie em extinção. USP, São Paulo.Tese de Doutorado.

FONTOURA, Luiz F. M. (2004) A produção social do espaço agrário. In: VERDUM, R. BASSO, L. SUERTEGARAY, D. Rio Grande do Sul: paisagens em transformação. Editora da UFRGS. Porto Alegre.

FRANTZ, Telmo R. (1982) Cooperativismo empresarial e desenvolvimento agrícola - o caso da Cotrijuí. Ijuí, Editora da FIDENE.

FRANZEN, B. V. (2005) Jesuítas portugueses e espanhóis no sul do Brasil e Paraguai coloniais. Editora da UNISINOS. São Leopoldo.

GARCIA, Fernando C. (2010) Fronteira iluminada. História do povoamento, conquista e limites do Rio Grande do Sul a partir do Tratado de Tordesilhas 1420-1920. Ed. Sulina, Porto Alegre.

HAESBAERT, Rogério. (2004) Territorialidades "gaúchas". In: VERDUM, R. BASSO, L. SUERTEGARAY, D. Rio Grande do Sul: paisagens em transformação. Editora da UFRGS. Porto Alegre.

LUGON, Clóvis.(2010) A República Guarani. Expressão Popular. São Paulo.

MAEDER, E.J. (2004) Missiones: historia de la tierra prometida. Eudeba. Buenos Aires.

ORNELLAS, Manoelito. (1956) Gaúchos e Beduínos. A formação étnica e a formação social do Rio Grande do Sul. $2^{\mathrm{a}}$ ed. Livraria José Olympio Editora. Rio de Janeiro.

SANTOS, Milton. (1979) Espaço e sociedade. Ed. Vozes Petrópolis. . (2008) Espaço e método. 5aed. Edusp. São Paulo. 
SILVA, Lígia. O. (1996) Terras devolutas e latifúndio: efeitos da Lei de Terras de 1850. Unicamp. Campinas.

WAIBEL, Leo. (1958) Capítulos de geografia tropical e do Brasil. IBGE. Rio de Janeiro.

ZARTH, Paulo. A.(2002) Do arcaico ao moderno, o Rio Grande do Sul agrário do século XIX. Ed. UNIJUÍ. Ijuí.

Internet consultada:

http://www.seplag.rs.gov.br/atlas/atlas.asp?menu=26. Acessado em: 20 de mai. 2011. 